\title{
Introduction to the Classic Edition
}

\author{
James E. Post
}

Private Management and Public Policy was published in 1975 as one in a series of books on economic institutions and social systems. This collection of titles was spearheaded by series editors Dow Votaw and S. P. Sethi of University of California at Berkeley. Our particular project was an outgrowth of a series of courses and modules that Lee Preston and his colleagues developed, first at Berkeley and later at the State University of New York at Buffalo. Their common effort to craft a curriculum focused on the public policy environment of management wove together two decades of thinking, writing, and teaching. This work proved to be an important contribution to a national trend in business education and business practice.

In this introduction to the Classic Edition, we review the history of this project, three key themes that have contributed to the development of the field, and the response of colleagues to these ideas.

\section{DEVELOPMENT OF THE FIELD OF BUSINESS AND SOCIETY}

As the original foreword mentions, the field vaguely called "business and society" was beginning to come into focus by the 1970s. The field's academic roots can be found in the writings of economist J. M. Clark (1916), but its modern development did not begin until the 1950s with publication of Howard Bowen's book The Social Responsibilities of the Businessman (1953) and the endorsement of Standard Oil of New Jersey (Exxon) CEO Frank Abrams who wrote in Harvard Business Review (1951) of the responsibilities of management to "conduct an equitable and workable balance" among the claims of various interested groups. By the early 1970s, when I met Lee, the field was in a state of ferment and creativity. Business and society courses were being taught at Berkeley, Columbia, Pittsburgh, UCLA, University of Washington, and other universities. In 1971, the Academy of Management created the Social Issues in Management division to support faculty teaching and research in the field. Three years later in 1974, the American Association of Collegiate Schools of Business (AACSB) revised its standards to require all AACSB-accredited schools to teach courses in 
the non-market (legal, ethical, social, political, and regulatory) environment of business as part of the "common body of knowledge."

Significant changes were taking place in the world of business practice as well. Outside of the university, the public policy environment was becoming enormously complicated and "textured"- -both in the United States and around the world. The social pressures that arose in the 1960s around civil rights, the natural environment, consumer protection, and employee health and safety, for instance, produced a torrent of regulatory and legislative activity in Washington DC. Economic regulation, which had expanded rapidly since the 1930s, was accompanied in the 1970s by a large number of social regulations, which cumulatively imposed a heavy financial and operational burden on many industries and business enterprises. Business leaders struggled to understand and respond to this turbulent public policy environment.

The 1970s were an era of acute economic distress as a slowly growing domestic economy was challenged by the OPEC oil shortages and consequent price increases beginning in 1973. The "oil shock" was one of the great economic and political markers of the twentieth century, and it signaled the end of Western economic hegemony that depended on and assumed inexpensive, plentiful, and reliable oil energy supplies. Within a few months, retail gasoline prices skyrocketed in the United States and Europe, plunging consumers into a panic as long lines at retail gasoline stations defined the shortages and produced images for the nightly news. America could not run without abundant oil, and the reality of the shortage was economically and psychologically stifling. The industrial impact was more severe, and the economy struggled to operate on highly uncertain supplies of oil, the price of which increased sharply. The result was significant industrial disruption, economic inflation, and political stress. The Nixon (1969-74), Ford (1974-77), and Carter (1977-81) administrations each struggled (mostly in vain) to curb inflation, improve employment, and restore economic growth. During these presidencies, the intersection of private management decisions and public policy decisions was sharply defined. Economic policy making affected industrial action and direction, businesses struggled to adapt to new realities, and companies could not make long-term strategic decisions in such an unsettled public policy environment.

I came to this field as a young lawyer with an interest in antitrust law and the changing relationship between management and labor. I met Lee Preston in a graduate class that he taught at SUNY Buffalo on market structures and competition policy. Lee was a distinguished economist specializing in the analysis of how industry market structures affected the economic and social performance of firms. He had taught at UC Berkeley and served as a staff economist for the president's Council of Economic Advisers during the Kennedy administration. During the OPEC oil crisis, he consulted with federal agencies, including the Federal Trade Commission, on the behavior of oil producers, refiners, and marketers. These issues excited me, and I began working with Lee and other distinguished 
faculty members including C. Perry Bliss (marketing), Joseph Shister (industrial relations), and Philip Ross (labor law). Our book was the direct result of these early collaborations.

Private Management and Public Policy was written in response to the powerful trends and developments of the day, and the book's title reflected what Lee and I saw as the core relationship and critical tension at the eye of the storm. Private management - the freedom to chart the course of each firm independently-was under assault. The great social movements of the era had radically transformed business decision making during this era. Managers could not manage their enterprises in the same old way-with an old world view. The world was different, and it was incumbent on leaders to recognize the need for what General Electric's CEO, Reginald Jones, called a "new breed" of business executives (Carroll et al. 2012). Public policy —in its many forms - was significantly intruding on business decisions-affecting products, processes, human resources, and corporate strategy. We understood the difficult struggle that businesses were engaged in, but we also observed the leadership of executives who were effectively engaging these issues. Private Management and Public Policy both analyzed what was happening in the public policy environment, and why, and provided dozens of examples of companies whose managers were responding effectively to the nonmarket environment. Even today, forty years later, many of these examples illuminate management choices and best practices that have stood the test of time.

\section{A NEW APPROACH}

Our perspective in Private Management and Public Policy was rooted in systems theory, and we conceptualized business and society as systems that "interpenetrated" each other, both affecting — and being affected by - the other. (See references to Talcott Parsons, L. von Bertalanffy, and Kenneth Berrien in Chapter 2.) In our view, the influence of each system was felt primarily through processes of contractual (market) exchange and public policy. This perspective built on the views of other systems thinkers of the era whose publications included Lawrence and Lorsch, Organization and Environment (1967); James Thompson, Organizations in Action (1967); and later, Pfeffer and Salancik, The External Control of Organizations (1978). Many of these scholars recognized the challenges presented by the external environment without explicitly addressing the business-society relationship. Read together, however, these books constitute a foundation of organizational systems thinking that enabled us to analyze the systemic relationship of business and society.

Private Management and Public Policy offers readers a new conceptual lens through which to compare the market contract, legal, exploitation, and technocratic models that characterized the existing literature. Together, they allowed us to introduce the interpenetrating systems model as a modern alternative to the limited models of the past. 
This systems framework encouraged managers and scholars to see public expectations as integral to the dynamics of business strategy and operations, not "add-ons" to a mythical, economics-only purpose. This concept supported three central themes, each of which represented a change in the study of business and society in the 1970s and which have continued to evolve over four decades. These themes have affected the way we think about corporate responsibility and the interface between private management and the public policy process. Let us examine each theme more closely.

\section{Theme 1: Corporate Social Responsiveness}

The first theme flowed from the recognition that managers and firms were engaged in a host of activities and processes as they responded to the changing public policy environment. We closely observed and analyzed the responsiveness of firms to their diverse constituencies (stakeholders), and to the issues and concerns of society as a whole. In 1971, the Committee for Economic Development (CED), an association of large companies, issued a statement entitled the "Social Responsibilities of Business Corporations," which advocated for a "government-business partnership for social progress." But how was this to be done? As we discussed in Private Management and Public Policy, there were many examples of creative business responses to social issues. As we reported in subsequent works (Post 1976; 1978), this research helped to ground a body of work that would become known as "corporate social responsiveness" (Ackerman 1975; Frederick 1994; Frederick 1998).

As Carroll (2008) and others (Carroll et al. 2012) have reported in their histories of the corporate responsibility movement, Private Management and Public Policy marked a turning point by substituting the more-precise directives of public policy for the rather vague idea of "social" responsibility. Our book also placed an emphasis on meeting the "how-to" challenge of responding to public issues.

Those working on corporate social responsiveness eventually focused on how corporations learned to more effectively plan, organize, and execute social programs, including the characteristics and capabilities of those managers who became public affairs professionals (Post et al. 1980; 1983). In time, this line of research would evolve into a deeper, more-comprehensive understanding of how corporate responsiveness to local issues and communities developed into the "corporate community relations" field (Burke 1999) and later, into the field now known as "corporate citizenship." Today, this work has become integral to the discussion of sustainability as an environmental, community, and societal imperative for business (Waddock and Rasche 2012).

\section{Theme 2: The Corporation as Political Actor}

The second theme focused on the corporation as a political actor. Private Management and Public Policy explicitly addressed the role of the corporation 
in the public policy process. The 1970s witnessed the rapid expansion of public policy as a relevant factor in corporate strategy and performance. Public policy impacted firms in many industries, including government contractors in the defense and energy industries. By the early 1970s, corporate public affairs offices were opening at a rapid rate in Washington DC and state capitals. But there was serious assault on corporate integrity in the political arena during the 1970s. Political graft, illegal campaign contributions, and a "revolving-door" job market that drew government employees to private sector jobs-often to lobby their former departments and colleagues-were commonplace. The Watergate scandal exposed a veritable "octopus" of corporate and political corruption that extended from the White House to corporate suites at Gulf Oil, Lockheed, ITT, and many other companies. The scandals galvanized significant reform action, including new rules for corporate political spending and passage of the precedent-setting Foreign Corrupt Practices Act. Ethical norms were reset in industries such as defense and government contracting, and illustrated the interpenetration of business and politics and the capacity of our institutional systems of constitutional government-two key concepts discussed in this text-to generate reforms.

Our colleague, Edwin Epstein, named the problem of corporate political activity in his book The Corporation in American Politics (1969). We in turn addressed the corporation as a legitimate participant in American political life in Private Management and Public Policy, sharing Epstein's view that the case for corporate political participation rests on the fact that corporations have legitimate political concerns, goals, and interests that should be placed on a legal parity with other social interests in the democratic process. Conversely, the argument against corporate political participation rests on the disparity in size and power between a corporation and an individual and, secondarily, on the fact that corporate managers are not duly elected representatives of the public. Some management experts go further, arguing that political participation is an inappropriate function for managers who should devote their time and effort to market-oriented goals and the pursuit of profits (as if these roles could be separated). Ironically, this is the same type of argument that critics used to oppose corporate social involvement. In both instances the argument falls short. Once it is acknowledged that firms have a strategic interest in the outcome of a public policy decision (e.g., taxation, market regulation, trade practices), it is naïve to believe that management resources will not be devoted to securing that interest. Forty years after Epstein's framing, and our own analysis, there is no question that business involvement in public policy is here to stay.

Both perspectives - for and against-were central to our discussion of corporate political participation and our belief that such participation, while legitimate, requires clear standards of openness, balance, and accountability. During the 1980s, business involvement in reshaping public policy led to less-onerous taxation, deregulation, more capital formation, and innovation. Forty years later, in a world of super PACs and media scrutiny unlike any past era, the caveats that 
we called out for the corporate and political partnership to work remain valid, despite the vast changes in contemporary political life.

Many regulations have been imposed on corporate political activity in an effort to control excesses. The U.S. Supreme Court's fateful decision in the Citizens United case (2010), wherein corporate political speech was equated with individual political free speech, has created a new landscape for corporate political action. The new realities of the electoral and public policy environments have created a hotbed for business and society scholars as well as political scientists. The political activities of corporate entities are drawing intense scrutiny since the Citizens United case, and the legitimacy, limits, and impact of corporate political behavior-and corporate political power-are certain to continue as vital topics of business and society research for decades to come.

During one of our last conversations, Lee Preston, who passed away in 2011, wondered whether our recommendation that corporations look to public policy as a guide to responsibility had been naïve. In a world of state capitalism on the global front and toxic politics on the domestic front, public policy formation is no longer the honorable activity it once seemed to be. We concluded that over the long run, the interpenetrating systems and institutional systems models remain conceptually sound, although the current political era presents troubling distortions in public policy making. These concepts continue to provide useful conceptual tools to scholars and managers who are trying to disentangle complicated realities in the post-Citizens United environment. For the modern corporation, it remains imperative to look to a nation's public policy as the legitimate guide to its market and non-market responsibilities.

\section{Theme 3: The Logic and Limits of Corporate Responsibility}

The third theme that emerged from Private Management and Public Policy was an understanding that the modern enterprise, especially the large corporation, was engaged in a dual logic — an "economizing logic" that guided its use of resources and a "legitimizing logic" that guided its behavior to meet the expectations of demanding societal and political environments. This idea was offered by Howard Bowen, whose book Social Responsibilities of the Businessman, is generally acknowledged to be the seminal beginning of our area of study in the 1950s. Bowen observed that "in general, business is sensitive to changes in the market for its goods and it is equally sensitive to changes in the market for the business system itself" (Bowen 1953, 106). He elaborated on that notion, recognizing that corporate leaders always needed to keep one eye on the public's approval of business while keeping the other eye on competitive market practices. History demonstrates the essential truth of Bowen's observation as industry after industry, from the railroads in the nineteenth century to Facebook in the twenty-first century, has faced the dual challenge of achieving market success 
while also achieving or maintaining public legitimacy. The practice of corporate responsibility - or "public responsibility" as we called it in Private Management and Public Policy — reflects the recognition and reality of this dual thought process.

For two centuries, Americans have tried to reconcile two realities of capitalism. Corporations, capitalism's dominant organizational form, have become very efficient mechanisms for creating wealth, meeting consumer demand, and building industries that employ millions. Yet corporations also impose costly externalities on communities and the natural environment and cause transformational change. Government, citizens, and business leaders themselves have responded by insisting that corporations-individually and as a group-must assume responsibility for more than their narrow economic interests.

Social issues are a constant presence in the life of businesses. Rarely, if ever, does a manager face only economic issues. More often, decision making is crowded with a mix of competitive, personnel, community, environmental, and ethical considerations. Decisions about "doing the right thing" are made within this cacophony of "decision noise." This reflects our view that corporate responsibility arises from, and is part of, the primary activities of the firm.

Private Management and Public Policy addresses one of the most vexing and central questions for managers and business and society scholars: What are the limits of corporate responsibility? This question provoked a decades-long debate in the lead-up to the book, with some (e.g., Milton Friedman) arguing for a narrow answer ("fundamentalism"), while others advocated for a more expansive response ("social involvement").

In Private Management and Public Policy, we recognize the legitimacy of the "limits" question and the strength of the "pro" and "con" positions: No firm can have unlimited responsibilities for everything, and yet no firm can reasonably expect society to hold it accountable for nothing. The difficult part for managers and citizens alike is to define logical lines of demarcation - and practical guidelines-based on what the firm actually does and the impact it actually has on society. The principle of public responsibility (as it is called in this book) extends the firm's responsibility to its primary involvement (those things it chooses to do) and secondary involvement (those impacts that flow from its primary activities), but no further. Thus, managers can anticipate that they and their firm will be held accountable for the consequences and effects (externalities) of the decisions and activities in which they engage, and hence, can foresee and anticipate society's legitimate expectations. As the saying goes, "Actions have consequences ... and then you're responsible." But the scope of responsibility is not unlimited, and while a firm may voluntarily undertake additional activities (e.g., philanthropic donations), it should neither be pressured to do so nor should it (as a colleague wrote) try to "buy off its core responsibilities, such as cleaning up its air and water pollution, with a few philanthropic contributions to the opera" (Logsdon 
1996). The principle of public responsibility proved to be a workable definition of how far the firm's responsibility extended. Lee and I often engaged with managers who pointed to our public responsibility argument as providing clear, useful guidance.

The "logic and limits" problem continues in the twenty-first century. One area of continuing debate involves preservation of the natural environment and achievement of environmental and social sustainability. Landmark catastrophes have occurred in every decade since the 1970s: The Bhopal plant explosion in 1984, Exxon Valdez oil spill in 1989, Brent Spar oil rig controversy in 1995-96, British Petroleum Deepwater Horizon blowout in the Gulf of Mexico in 2010, and Costa Concordia shipwreck off the Italian coast in 2012. Each disaster raises anew issues of liability and accountability, and each provokes new corporate, industry, and public policy actions to redefine corporate responsibility. These incidents strengthen the case for a systemic approach to environmental sustainability, a topic that had barely been defined when this book first appeared. Systems analysis was a new approach in the 1970s; today, holistic thinking is fundamental to the way we understand networks, adaptive processes, and complex business and society issues. What was once defined as a problem of pollution controls and enforcement of emissions standards, for example, is now understood to be a challenge to think about the natural environment in a systemic way that incorporates an "economizing logic" with a "legitimizing logic."

\section{A GLOBAL EXTENSION OF OUR WORK}

The role of government in the domestic economy was the dominant public policy concern in the mid-1970s. But in the decades following the publication of this book, the study of business and society became a truly international field. Trade conflicts, export policies, taxation, and intellectual property protectionissues with important cross-border implications-were among the policy problems that concerned American business.

Many scholars in the business and society field were drawn to the international domain because of the human rights issues that accompanied the growth of global commerce. One of our concerns at the outset was the possibility that our argument for public responsibility might be misinterpreted as a justification for harsh or repressive governments to insist that corporations follow its specific policies, no matter how odious they might be. In nations such as South Africa, which enforced a policy of apartheid from 1948 to 1994, public policy demanded racial separation and required domestic and multinational companies to abide by local law. This put multinational companies in the difficult position of either obeying local law and suffering international pressure, or heeding international pressures and risking disobedience of South African law. During the 1980s, pressures mounted for companies to withdraw or otherwise stop doing business in South Africa, and an international boycott was launched in support of 
human rights. As we wrote our twentieth-anniversary symposium piece, "It must be recognized that the validity of public policy rests, in significant measure, on the legitimacy of the institutions that shape it." Military dictatorships, puppet governments, and other forms of illegitimate authority lack status among the community of nations. As demonstrated by the Arab Spring in 2011 (producing regime changes in Egypt, Libya, and Tunisia), international norms, standards, and accords form a framework of international cooperation that advocates for human rights and punishes breaches of international law.

Social issues, such as doing business in South Africa, introduced many scholars to the international arena. By the end of the 1980s, the world witnessed the collapse of communism and the liberalization of Eastern European economies that had been under communist rule for a half century. These changes produced great opportunities for business and society scholars. Lee Preston focused his attention on the global political and economic changes taking place in Eastern Europe. In the early 1990s, he undertook a study of comparative global governance regimes and the public policy dynamic that formed the underpinning for those systems (Preston and Windsor 1992). He also experienced the impact of these changes firsthand as he worked with colleagues in Poland to establish business education programs for the emerging market economy of that newly liberated nation.

My own global experiences complemented those of Lee. From 1984 to 1992, I served as a member of the Nestle Infant Formula Audit Commission, an oversight body designed to monitor that company's voluntary compliance with the WHO international marketing code. The experience gave me a deeper understanding of the significant obstacles facing a company that commits to implementing global policy. Since the early 1990s, I have worked with colleagues in Australia (Centre for Corporate Public Affairs) and elsewhere in the Asia-Pacific region in an effort to understand the evolution of the corporate public affairs function during a period of radical economic growth and change. While on leave, I also served as a research director of the business and society program at the Conference Board, whose members have addressed issues of business ethics and corporate responsibility in the global economy for more than 100 years.

The convergence of these international streams of work extended the ideas and arguments of Private Management and Public Policy to political economies outside the United States and to a new era of global business and society education. The conduct of multinational corporations has been a focus in business schools since the 1950s, but a new emphasis arose in the 1980s when Japanese companies dominated U.S. markets for steel, automobiles, and semiconductors. "Japan, Inc.," as it was called, reflected a form of cooperation between business and government that stood in sharp contrast to the more adversarial relationship between business and government in the United States. Public policy suddenly became a strategic interest for U.S. companies; business schools responded by 
making business-government relations part of the teaching of strategic management and by expanding business and society courses.

As communism collapsed, governance of corporations in new democracies drew heavily on the American experience. One thing became clear: Market liberalization required that companies also give attention to corporate responsibility and responsiveness issues. As Howard Bowen suggested in 1953, the business firm must be sensitive to changes in the market for its goods and to changes in the market for the business system itself. Private Management and Public Policy enjoyed a resurgence of interest in the 1990s as academics and policy thinkers in Eastern European nations sought to understand and create economic models of business and society that would promote both freedom and responsibility. These developments over the course of two decades meant that by the late 1990s, our book had established a new generation of readers in Asia and Eastern Europe, as well as the United Kingdom, Canada, and the United States.

In 1995, on the occasion of the twentieth anniversary of Private Management and Public Policy, a group of colleagues organized a "retrospective" forum with papers that analyzed and assessed the impact of our book (Business and Society 1996). We used our "last word" to forecast an important extension of these ideas when we wrote:

If we could add one point to the theme presented by the contributors, it would be that the interpenetrating systems model shows business management to be involved in multiple simultaneous interactions with other elements of society. ... The picture is not simply one of "business" on one side, and "society" on the other. Instead, the firm —and the business system as a whole-is constantly dealing with multiple interests at the same time. This point is best pursued through stakeholder analysis, which we believe to be an appropriate means of applying the broad concept of the interpenetrating systems model in practical affairs.

By the mid-1990s, stakeholder analysis had become a foundational idea for business and society research (Freeman 1984). What we described conceptually as "many publics" in Private Management and Public Policy came to be understood as "stakeholders" whose contributions enable a firm to achieve its strategic goals and objectives. In the late 1990s, stakeholder research took a major step forward when Lee Preston, Tom Donaldson, and Max Clarkson created a consortium of researchers in a multiyear project on the "stakeholder corporation" with support from the Alfred P. Sloan Foundation. One of the products of this research was our collaboration with Sybille Sachs, resulting in the book Redefining the Corporation: Stakeholder Management and Organizational Wealth, also published by Stanford University Press (Post et al. 2002). In this book, we contrasted three basic views of the modern corporation: the industry structure view 
(ISV), resource-based view (RBV), and stakeholder view (SHV). We related these views to the experience of the many companies studied in the Sloan project. The interpenetrating systems view, first elaborated in Private Management and Public Policy, has now been directly linked to the network and institutional theories of the firm that populate the modern research literature (Sachs and Rühli 2011). The next challenge involves linking such theories to our understanding of the decision making of private management in a world of public policy regimes.

\section{ACKNOWLEDGMENTS AND DEDICATION}

I am confident that in 1975, neither Lee Preston nor I anticipated that readers would still find value in "our little book" nearly four decades after its original publication. Indeed, we rejected invitations to produce new editions on several occasions, doubting that we could add much to the original. Our agreement to undertake this re-publication was due to a confluence of factors.

First, our colleagues, led by Shawn Berman, collaborated in the design and delivery of a thirty-fifth-anniversary symposium to assess the book's contribution at the Academy of Management in Montreal in August 2010. Lee and I were gratified by the care that participants took in discussing our work and the symposium inspired us to seriously consider the calls for republication that occurred at that meeting. Second, Margo Beth Fleming of Stanford University Press proved to be a patient editor whose confidence in this project never faltered. She deserves credit and thanks for her vision to include Private Management and Public Policy in the Stanford University Press "Stanford Business Classics" series. Without either of these actions, I feel certain that we would not have considered re-publication. Among the colleagues who have been especially helpful to this project are professors Shawn Berman, Sybille Sachs, and Sandra Waddock. They bear no responsibility for errors or omissions but have earned our thanks for their insight and wisdom.

Shortly after we began working on this re-publication project, Lee was confronted with a number of serious medical problems. As I noted earlier, he died in November 2011, shortly after his eighty-first birthday. Sadly, this introduction to the Classic Edition reflects only some of what we hoped to do and what we hoped to pass on to young scholars in business and society. Lee Preston's death is a great personal loss, and it is a loss for the many professional colleagues who knew him and his work. Throughout his fifty-year career, Lee's creative spirit meshed with his determination to make business and society a serious field of academic study. Through each of his many and varied efforts, Lee conveyed a sense of joy and a commitment to excellence, clear writing, and scholarly integrity. Lee Preston painted on a canvas as wide as the academic areas in which he worked. This Classic Edition is dedicated to his memory, and I hope that it inspires many young readers to follow in the footsteps of his career, ever expanding on the foundation of Private Management and Public Policy. 


\section{REFERENCES}

Abrams, F. 1951. "Management's Responsibility in a Complex World." Harvard Business Review, May: 29-34.

Ackerman, R. 1973. "How Companies Respond to Social Demands." Harvard Business Review, July-August: 88-98.

-1975. The Social Challenge to Business. Cambridge, MA: Harvard University Press.

Bowen, H. 1953. Social Responsibilities of the Businessman. New York: Harper and Bros.

Burke, E. 1999. Corporate Community Relations: The Neighbor of Choice Principle. Westport, CT: Quorum Press.

Business and Society (vol. 35, no. 4) Special Forum: "A 20-Year Retrospective on Preston and Post's Private Management and Public Policy: Perspectives on the Influences of Interpenetrating Systems Theory." 439-482.

Carroll, A. B. 2008. "A History of Corporate Social Responsibility: Concepts and Practices," Chapter 2 in A. Crane, A. McWilliams, D. Matten, J. Moon, and D. Siegel, eds., Oxford Handbook of Corporate Social Responsibility. New York: Oxford University Press.

Carroll, A. B., K. Liparitito, J. Post, and P. Werhane; K. Goodpaster, ed. 2012. Corporate Responsibility: The American Experience. New York: Cambridge University Press.

Clark, J. M. 1916. "The Changing Basis of Economic Responsibility." Journal of Political Economy 24 (3): 209-229.

Epstein, E. M. 1969. The Corporation in American Politics. Englewood Cliffs, NJ: Prentice Hall, Inc.

Frederick, W. C. 1994. "From CSR1 to CSR2." Business and Society 33 (2): $150-164$.

- 1998. "Moving to CSR4: What to Pack for the Trip." Business and Society 37 (1): 40-59.

Freeman, R. E. 1984. Strategic Management: A Stakeholder Approach. Boston: Pitman Publishing, Inc.

Lawrence, P., and J. Lorsch. 1967. Organization and Environment: Managing Differentiation and Integration. Cambridge, MA: Harvard University Press.

Logsdon, J. M. 1996. "Just a Classic? Assessment and Reflections on Private Management and Public Policy," Business and Society (vol. 35, no. 4) Special Forum: "A 20-Year Retrospective on Preston and Post's Private Management and Public Policy: Perspectives on the Influences of Interpenetrating Systems Theory." 451-458.

Pfeffer J., and G. R. Salancik. 1978. The External Control of Organizations: A Resource Dependence Perspective. New York: Harper \& Row, Inc. (Reprinted in 2003 by Stanford University Press). 
Post, J. 1976. Risk and Response: Management and Social Change in the American Insurance Industry. Lexington, MA: DC Heath Inc.

- 1978. Corporate Behavior and Social Change. Reston, VA: Reston Publishing Co.

Post, J., E. A. Murray, R. B. Dickie, and J. F. Mahon. 1980. “The Public Affairs Function in American Corporations: Development and Relations with Corporate Planning." Long Range Planning 15 (2): 12-21.

. 1983. "Managing the Public Affairs Function." California Management Review 24 (1): 135-150.

Post, J., L. E. Preston, and S. Sachs. 2002. Redefining the Corporation: Stakeholder Management and Organizational Wealth. Palo Alto, CA: Stanford University Press.

Preston, L. E., and D. Windsor. 1992. The Rules of the Game in the Global Economy: Policy Regimes for International Business. Dordrecht, The Netherlands: Kluwer.

Sachs, S., and E. Rühli. 2011. Stakeholders Matter: A New Paradigm for Strategy in Society. Cambridge: Cambridge University Press.

Thompson, J. 1967. Organizations in Action. New York: McGraw-Hill, Inc.

Waddock, S., and A. Rasche, 2012. Building the Responsible Enterprise. Palo Alto, CA: Stanford University Press. 
